\title{
Effects of histamine on lung permeability in normal and asthmatic subjects
}

\author{
PJ REES, D SHELTON, TB CHAN, N EISER, TJH CLARK, MN MAISEY \\ From the Departments of Thoracic Medicine and Nuclear Medicine, Guy's Hospital, London
}

\begin{abstract}
The permeability of respiratory mucosa, as measured by clearance of diethylenetriamine penta-acetate (DTPA) labelled with technetium $99 \mathrm{~m}$, was similar in seven normal and nine asthmatic subjects. Histamine induced bronchoconstriction was associated with a $50 \%$ increase in permeability in both groups of subjects. In normal subjects inhaled salbutamol, given as $1 \mathrm{mg}$ acutely or as $200 \mu \mathrm{g}$ four times daily for two weeks, had no effect on pulmonary permeability. Salbutamol, given before histamine challenge, prevented bronchoconstriction, but did not affect the increase in permeability seen in normal subjects. Low doses of histamine, sufficient to cause bronchoconstriction in the asthmatic subjects, produced little bronchoconstriction in normal subjects but caused increases in lung permeability similar to those seen in asthmatic subjects. These studies suggest that these two effects of inhaled histamine, bronchoconstriction and increased permeability, are independent.
\end{abstract}

The cause of increased responsiveness of the airways in asthma is unknown. One possible cause might be that the respiratory mucosa is abnormally permeable to antigens and mediators of allergic responsiveness. Although it was suggested that permeabitity may be increased in asthma, Elwood et $a^{2}$ showed that permeability was no greater in 10 subjects with stable asthma than in nine normal subjects. When bronchoconstriction was induced by inhaled histamine, however, permeability increased in both normal ${ }^{23}$ and asthmatic ${ }^{3}$ subjects, while exposure to specific antigen was found to increase permeability in allergic monkeys. ${ }^{4}$ Thus although increased respiratory mucosal permeability is not a primary underlying abnormality in stable asthma it might play a part in the development of bronchoconstriction induced by various stimuli. In this study we have examined the characteristics of histamine induced permeability changes in normal and asthmatic subjects, and investigated the effects of salbutamol on these changes.

\section{Methods}

SUBJECTS

Seven non-asthmatic subjects, aged 20-40 years,

Address for reprint requests: Dr PJ Rees, Guy's Hospital, London SE1 9RT.

Accepted 8 March 1985 were studied. None was having any medication. One subject, whose results are indicated in table 3 , was a smoker. In addition, nine non-smoking asthmatic subjects, aged $20-55$ years, were studied. They were having various inhalation treatments, but all treatment was withheld for at least four hours before the studies.

MEASUREMENT OF PULMONARY PERMEABILITY Pulmonary epithelial permeability was measured by

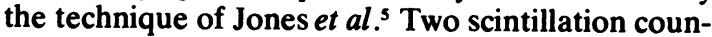
ters were used, one centred $7 \mathrm{~cm}$ below the midpoint of the right clavicle and one over the middle of the left thigh, directed away from the bladder. DTPA (diethylenetriamine penta-acetate, molecular weight 492 daltons) labelled with technetium $99 \mathrm{~m}$, in a concentration of $0.5 \mathrm{mCi} / \mathrm{ml}$ normal saline, was inhaled from a Hudson nebuliser, via a particle separator comprising a column of beads. The mass median diameter of the aerosol droplets was $0.9 \mu \mathrm{m}$. The subject, wearing a noseclip, inhaled the aerosol through a mouthpiece by tidal breathing for two to three minutes until the lung scintillation counter registered about 2000 counts per minute. Throughout the study subjects lay still on a couch with a backrest at $30^{\circ}$. Counting continued for 60 out of every 90 seconds until the count had fallen by about $50 \%$. Subsequently, a bolus of $50 \mu \mathrm{Ci}$ of ${ }^{99 \mathrm{~m}}$ Tc DTPA was administered intravenously. From the ratio of the increases in thigh and 
604

lung counts, ${ }^{5}$ a correction factor for tissue radioactivity in the field of the lung probe was calculated. The corrected lung count was used to calculate the half time clearance of ${ }^{99 \mathrm{~m}}$ Tc DTPA, as a measure of the permeability of lung epithelium. On each occasion the linear correlation coefficient between log corrected count and time was 0.90 or greater.

\section{HISTAMINE CHALLENGE STUDIES}

All subjects underwent bronchial challenge with histamine in a standardised fashion ${ }^{6}$ for estimation of the dose of histamine required to decrease baseline specific airways conductance by about $50 \%$. Pulmonary permeability was measured in six non-smoking normal and nine asthmatic subjects. Pulmonary counting was carried out until sufficient readings were available to calculate the half time clearance of ${ }^{99 \mathrm{~m}}$ Tc DTPA. Five submaximal breaths of histamine were then inhaled from a Hudson nebuliser and the counts continued for a further 10 minutes. The dose ranges of histamine were $10-100 \mathrm{mg} / \mathrm{ml}$ for normal subjects and $0.4-8 \mathrm{mg} / \mathrm{ml}$ for asthmatic subjects. Histamine acid phosphate was diluted in normal saline.
Rees, Shelton, Chan, Eiser, Clark, Maisey

The effect of histamine on pulmonary epithelial permeability was also studied in normal subjects 20 minutes after they had inhaled $1 \mathrm{mg}$ salbutamol via 10 actuations from a metered dose inhaler. On another occasion measurements of pulmonary epithelial permeability were made in the normal subjects before and after histamine at a dose of $0.2 \mathrm{mg} / \mathrm{ml}$ (the mean concentration given to asthmatic patients) and continued after a further challenge with histamine at the concentration known to decrease specific airways conductance by $50 \%$.

Recordings of peak expiratory flow rate (PEFR) were made before and every five minutes after histamine inhalation. The decrease in PEFR was taken as the difference between baseline and minimum values after histamine.

\section{Effect of salbutamol on pulmonary permeability} In seven subjects, including one smoker, permeability was measured 20 minutes after the administration of $1 \mathrm{mg}$ salbutamol via 10 actuations of a metered dose inhaler. In six subjects, including one smoker, permeability was measured before and after a one week course of inhaled salbutamol, $200 \mu \mathrm{g}$

Table 1 Effect of inhalation of histamine on ${ }^{99} \mathrm{~m}$ Tc DTPA clearance in nine asthmatic and six normal subjects ASTHMATIC SUBJECTS

\begin{tabular}{|c|c|c|c|c|c|}
\hline \multirow[t]{2}{*}{ Subject No } & \multirow{2}{*}{$\begin{array}{l}\text { Histamine } \\
\text { concentration } \\
\left(m g l^{-1}\right)\end{array}$} & \multicolumn{2}{|c|}{ DTPA clearance (min) } & \multicolumn{2}{|c|}{ Peak flow rate $\left(l \min ^{-1}\right)$} \\
\hline & & Before & After & Before & After \\
\hline $\begin{array}{l}1 \\
2 \\
3 \\
4 \\
5 \\
6 \\
7 \\
8 \\
9\end{array}$ & $\begin{array}{l}0.4 \\
8 \\
2 \\
1 \\
1 \\
0.8 \\
1 \\
8 \\
1\end{array}$ & $\begin{array}{l}53.7 \\
60.7 \\
40.8 \\
44.1 \\
59.2 \\
31.5 \\
75.9 \\
48.5 \\
50.6\end{array}$ & $\begin{array}{l}30.8 \\
48.3 \\
33.5 \\
24.3 \\
39.0 \\
22.7 \\
30.4 \\
19.6 \\
23.0\end{array}$ & $\begin{array}{l}475 \\
385 \\
520 \\
540 \\
500 \\
560 \\
570 \\
450 \\
480\end{array}$ & $\begin{array}{l}380 \\
180 \\
330 \\
270 \\
280 \\
480 \\
505 \\
160 \\
440\end{array}$ \\
\hline $\begin{array}{l}\text { Mean } \\
\text { SD }\end{array}$ & & $\begin{array}{l}51.7 \\
12.8\end{array}$ & $\begin{array}{r}30.2 \\
9.2\end{array}$ & $\begin{array}{r}498 \\
58\end{array}$ & $\begin{array}{l}336 \\
125\end{array}$ \\
\hline $\begin{array}{l}t \\
\mathrm{p}\end{array}$ & & \multicolumn{2}{|c|}{$\begin{array}{c}5.45 \\
<0.001\end{array}$} & \multicolumn{2}{|c|}{$\begin{array}{c}5.20 \\
<0.001\end{array}$} \\
\hline
\end{tabular}

NORMAL SUBJECTS

\begin{tabular}{|c|c|c|c|c|c|c|c|c|}
\hline \multirow[t]{2}{*}{ Subject No } & \multicolumn{2}{|c|}{$\begin{array}{l}\text { Histamine concentration } \\
\left(m g \mathrm{ml}^{-1}\right)\end{array}$} & \multicolumn{3}{|c|}{ DTPA clearance (min) } & \multicolumn{3}{|c|}{ Peak flow rate $\left(l \min ^{-1}\right)$} \\
\hline & $A$ & $B$ & Baseline & After $A$ & After $B$ & Baseline & After $A$ & After B \\
\hline $\begin{array}{l}1 \\
2 \\
3 \\
4 \\
5 \\
6\end{array}$ & $\begin{array}{r}2 \\
2 \\
2 \\
2 \\
2 \\
2\end{array}$ & $\begin{array}{r}20 \\
16 \\
20 \\
128 \\
32 \\
32\end{array}$ & $\begin{array}{l}54.4 \\
56.6 \\
43.6 \\
66.2 \\
66.8 \\
69.4\end{array}$ & $\begin{array}{l}17.5 \\
33.4 \\
31.2 \\
44.9 \\
31.4 \\
41.4\end{array}$ & $\begin{array}{l}24.2 \\
34.4 \\
22.2 \\
42.6 \\
27.1 \\
43.4\end{array}$ & $\begin{array}{l}540 \\
580 \\
605 \\
690 \\
440 \\
460\end{array}$ & $\begin{array}{l}460 \\
550 \\
510 \\
660 \\
380 \\
440\end{array}$ & $\begin{array}{l}340 \\
195 \\
340 \\
210 \\
180 \\
175\end{array}$ \\
\hline $\begin{array}{l}\text { Mean } \\
\text { SD }\end{array}$ & & & $\begin{array}{r}59.5 \\
9.8\end{array}$ & $\begin{array}{r}33.3 \\
9.6\end{array}$ & $\begin{array}{r}32.2 \\
9.2\end{array}$ & $\begin{array}{r}551 \\
85\end{array}$ & $\begin{array}{l}498 \\
109\end{array}$ & $\begin{array}{r}240 \\
78\end{array}$ \\
\hline $\begin{array}{l}t \\
\mathrm{p}\end{array}$ & & & \multicolumn{2}{|c|}{$\begin{array}{l}6.95 \\
<0.001\end{array}$} & & \multicolumn{2}{|c|}{$\begin{array}{c}4.4 \\
<0.01\end{array}$} & $\begin{array}{r}4.92 \\
<0.01\end{array}$ \\
\hline
\end{tabular}


four times a day taken by metered dose inhaler. The measurement was performed 20 minutes after the final dose.

\section{ANALYSIS}

The half time clearance of ${ }^{99 \mathrm{~m}} \mathrm{Tc}$ DTPA was calculated by linear regression after logarithmic transformation of the corrected lung count. ${ }^{5}$ The half time clearance values after various interventions were compared by paired $t$ tests.

The mean coefficient of variation of the clearance was calculated for the eight subjects for whom there was more than one baseline measurement. Measurements after salbutamol were used in this calculation after salbutamol had been found to have no significant effect on clearance. Thirty four measurements in eight subjects produced a mean coefficient variation of $14.5 \%$.

\section{Results}

There was no significant difference in baseline clearance of ${ }^{99 \mathrm{~m}} \mathrm{Tc}$ DTPA between asthmatic and normal subjects $(51.7 v 59.5 \mathrm{~min}$; table 1$)$.

\section{EFFECT OF INHALED HISTAMINE}

The peak expiratory flow rate fell by a mean of $55 \%$ after inhalation of histamine in the six normal subjects (table 2). The half time clearance of ${ }^{99 m} \mathrm{Tc}$ DTPA fell in all subjects by $50 \%$ (from 65.4 to 32.4 min; $p<0.001$ ). When histamine was preceded by salbutamol (1 mg) the fall in PEFR was much smaller (15\%) but the increase in the rate of clearance of ${ }^{99 \mathrm{~m}}$ Tc DTPA was $51 \%$, similar to that seen with histamine alone (from 64.5 to $31.8 \mathrm{~min} ; \mathrm{p}<0.01$ ).

In the nine asthmatic subjects low concentrations of histamine reduced PEFR by $33 \%$ and the clearance time by $42 \%$ (table 1 ).
In the six normal subjects given $2 \mathrm{mg} / \mathrm{ml}$ histamine clearance time fell by $44 \%$, while PEFR fell by only $9 \%$. Further inhalation of histamine at a concentration of $10-12.8 \mathrm{mg} / \mathrm{ml}$ caused another decrease in PEFR, by $48 \%$, but no further effect on clearance of ${ }^{99 \mathrm{~m}} \mathrm{Tc}$ DTPA.

\section{EFFECT OF SALBUTAMOL ON PULMONARY \\ PERMEABILITY}

Neither the acute administration of $1 \mathrm{mg}$ salbutamol by inhalation nor a week's course of $800 \mu \mathrm{g}$ salbutamol daily had any significant effect of DTPA permeability (table 3) in six normal subjects.

\section{Discussion}

Although our normal and asthmatic subjects were not matched for age, our results support previous findings that lung mucosal permeability is normal in patients with stable asthma. ${ }^{2}$ They also show that the inhalation of a selective $\beta_{2}$ stimulant has no effect on mucosal permeability.

Histamine inhalation has been shown previously to increase permeability ${ }^{2}$ and our results confirm these findings in both normal and asthmatic subjects. The prior inhalation of salbutamol in a dose sufficient to block most of the histamine induced bronchoconstriction did not affect the increase in permeability in the normal subjects. Although salbutamol was administered by metered dose inhaler and histamine by nebuliser, the particle size is similar and the lack of effect is unlikely to be related to a different distribution. Salbutamol was used in this way as this is the most common method of administration. This indicates that bronchoconstriction itself is unlikely to be an essential part of the change in permeability. The increased permeability after histamine inhalation is presumably related to a direct

Table 2 Effect of histamine with and without pretreatment with salbutamol on the lung clearance of technetium $99 m$ labelled diethylenetriamine penta-acetate in six normal subjects

\begin{tabular}{|c|c|c|c|c|c|c|c|c|}
\hline \multirow[t]{3}{*}{ Subject No } & \multicolumn{4}{|c|}{ Histamine } & \multicolumn{4}{|c|}{ Histamine and salbutamol } \\
\hline & \multicolumn{2}{|c|}{ Clearance (min) } & \multicolumn{2}{|c|}{ Peak flow $\left(l_{\min ^{-1}}\right)$} & \multicolumn{2}{|c|}{ Clearance (min) } & \multicolumn{2}{|c|}{ Peak flow $\left(l \min ^{-1}\right)$} \\
\hline & Before & After & Before & After & Before & After & Before & After \\
\hline $\begin{array}{l}1 \\
2 \\
3 \\
4 \\
5 \\
6\end{array}$ & $\begin{array}{l}63.5 \\
69.2 \\
76.2 \\
60.0 \\
71.0 \\
52.7\end{array}$ & $\begin{array}{l}38.3 \\
22.9 \\
45.4 \\
25.3 \\
40.4 \\
22.2\end{array}$ & $\begin{array}{l}530 \\
580 \\
490 \\
490 \\
730 \\
520\end{array}$ & $\begin{array}{l}320 \\
200 \\
320 \\
190 \\
150 \\
340\end{array}$ & $\begin{array}{l}74.3 \\
71.2 \\
45.8 \\
73.8 \\
86.7 \\
35.1\end{array}$ & $\begin{array}{l}42.2 \\
24.3 \\
22.1 \\
40.5 \\
32.1 \\
29.9\end{array}$ & $\begin{array}{l}520 \\
530 \\
500 \\
710 \\
610\end{array}$ & $\begin{array}{l}400 \\
495 \\
440 \\
550 \\
545\end{array}$ \\
\hline $\begin{array}{l}\text { Mean } \\
\text { SD }\end{array}$ & $\begin{array}{r}65.4 \\
8.5\end{array}$ & $\begin{array}{r}32.4 \\
9.2\end{array}$ & $\begin{array}{r}557 \\
91\end{array}$ & $\begin{array}{r}253 \\
82\end{array}$ & $\begin{array}{l}64.5 \\
17.9\end{array}$ & $\begin{array}{r}31.8 \\
7.6\end{array}$ & $\begin{array}{r}574 \\
87\end{array}$ & $\begin{array}{r}486 \\
73\end{array}$ \\
\hline $\begin{array}{l}t \\
\mathrm{p}\end{array}$ & \multicolumn{2}{|c|}{$\begin{array}{l}11.27 \\
<0.001\end{array}$} & \multicolumn{2}{|c|}{$\begin{array}{r}4.72 \\
<0.01\end{array}$} & \multicolumn{2}{|c|}{$\begin{array}{r}4.59 \\
<0.01\end{array}$} & \multicolumn{2}{|c|}{$\begin{array}{l}3.87 \\
<0.025\end{array}$} \\
\hline
\end{tabular}


Table 3 Effect of salbutamol on the clearance of technetium $99 \mathrm{~m}$ labelled diethylenetriamine penta-acetate $\left({ }^{99} \mathrm{~m}\right.$ Tc DTPA) from the lung

\begin{tabular}{|c|c|c|c|}
\hline \multirow[t]{2}{*}{ Subject No } & \multicolumn{3}{|c|}{ DTPA clearance (min) } \\
\hline & Baseline & After 1 mg salbutamol & After 1 week salbutamol \\
\hline $\begin{array}{l}1 \\
2 \\
3 \\
4 \\
5 \\
6 \text { (smoker) } \\
7 \text { (smoker) }\end{array}$ & $\begin{array}{l}61.3 \\
41.2 \\
90.4 \\
70.6 \\
85.3 \\
29.4 \\
27.4\end{array}$ & $\begin{array}{l}71.0 \\
39.9 \\
61.8 \\
65.8 \\
65.0 \\
32.0 \\
-\end{array}$ & $\begin{array}{l}81.7 \\
51.8 \\
70.8 \\
82.0 \\
68.1 \\
-31.1\end{array}$ \\
\hline $\begin{array}{l}\text { Mean }(1-6) \\
\text { Mean }(1-5+7) \\
\text { SD } \\
t\end{array}$ & $\begin{array}{ll}63.0 & \\
& 62.7 \\
10.8 & 10.1\end{array}$ & $\begin{array}{l}55.9 \\
7.1 \\
1.20 \text { (NS) }\end{array}$ & $\begin{array}{l}64.2 \\
8.8 \\
-0.23 \text { (NS) }\end{array}$ \\
\hline
\end{tabular}

effect of histamine on the epithelium, probably at the alveolar or terminal bronchiolar level. Borland et al have shown that a "fog" of distilled water can increase DTPA clearance from the lungs without inducing bronchoconstriction, ${ }^{7}$ although in this case the mechanisms of increased clearance may be related to osmotic change. We used histamine in normal saline to avoid this effect.

The much lower dose of histamine required to produce bronchoconstriction in asthmatic subjects produced a similar change in clearance in normal and asthmatic subjects. This also suggests that there is no direct relationship between the two effects of histamine in the lungs, bronchoconstriction and increased permeability. Braude $e^{2} \mathbf{l}^{8}$ have suggested that the bronchoconstrictor and permeability effects of histamine may be related to stimulation of different histamine receptors. Using histamine anatagonists they were able to block bronchoconstriction with an $\mathrm{H}_{1}$ blocker (terfenadine) and to inhibit the permeability change with an $\mathrm{H}_{2}$ blocker (ranitidine) in five normal subjects. Our results do not provide evidence of an increased susceptibility to histamine induced permeability change in asthma, although we did not give concentrations of histamine too dilute to produce bronchoconstriction in the asthmatic subjects. These findings suggest that abnormalities related to hyperreactivity to histamine in asthma relate to airway muscle but not to respiratory epithelium.
We are grateful for the help of Philip Chowienczyk in setting up the apparatus.

\section{Reference}

1 Hogg JC, Pare PD, Boucher RC, Michoud M-C, Guerzon G, Moroz LA. Pathologic abnormalities in asthma. In: Lichtenstein LM, Austin KF, eds. Asthma II. Physiology, immune pharmacology and treatment. New York: Academic Press, 1977:1-19.

2 Elwood RK, Kennedy S, Belzberg A, Hogg IC, Pare PD. Respiratory mucosal permeability in asthma. Am Rev Respir Dis 1983;128: 523-7.

3 O'Byrne PM, Dolovich M, Duvall A, Newhouse MT. Lung epithelial permeability after histamine challenge. Am Rev Respir Dis 1982;125:280.

4 Boucher RC, Pare PD, Hogg JC. Relationship between airway hyperreactivity and hyperpermeability in Ascaris-sensitive monkeys. J Allergy Clin Immunol 1979;64:197-201.

5 Jones JG, Minty BD, Royston D. The physiology of leaky lungs. $\mathrm{Br} J$ Anaesthiol 1982;54:705-21.

6 Eiser NM, Mills J, McRae KD, Snashell PD, Guz A. Histamine receptors in normal human bronchi. Clin Sci 1980;58: 537.

7 Borland C, Chamberlain A, Minty B, Royston D, Higenbottam $T$. Lung epithelial permeability changes after breathing a fine mist of distilled water but not after breathing cold air. Thorax 1983;38:221 (abstract).

8 Braude S, Royston D, Coe C, Barnes PJ. Histamine increases lung permeability by an $\mathrm{H}_{2}$-receptor mechanism. Lancet 1984;ii:372-4. 